PACS 88.20.fk

https://doi.org/10.15407/kataliz2021.32.040

\title{
Fuel-grade sunflower oil butyl esters: synthesis, purification, oxidation stability
}

\author{
S.V. Konovalov, S.O. Zubenko, L.K. Patrylak, A.V. Yakovenko \\ V.P. Kukhar Institute of Bioorganic Chemistry and Petrochemistry of the National Academy of Sciences of Ukraine, \\ 1, Murmanska str., Kyiv 02660,Ukraine, konovalovserhiy@gmail.com
}

Current paper deals with production, purification and oxidative stability enhancement of fuel-grade sunflower oil butyl esters as more ecological alternative of methyl esters as biodiesel. The oil feedstock, used in this study, included refined sunflower oil (acid value - $0.05 \mathrm{mg} \mathrm{KOH} / \mathrm{g} ; 25.3 \%$ of oleic and $61.2 \%$ of linoleic acids) and wasted frying high-oleic sunflower oil (acid value - $1.20 \mathrm{mg} \mathrm{KOH} / \mathrm{g} ; 6.1 \%$ of linoleic and $81.7 \%$ of oleic acids). Butanolysis was carried out using potassium butoxide, obtained from $\mathrm{KOH}$ and alcohols via original patent-pending method, under mild reaction conditions (alcohol-to-oil molar ratio $-4.5-5.0,15^{\circ} \mathrm{C}, 1.4-1.6 \%$ eq. кон of butoxide, $20-30 \mathrm{~min}$ ). High molar yield of butyl esters (93-96\%) was achieved, while glycerol and vast majority of alkaline catalyst formed the separate reaction products phase mainly in the course of reaction. Ester enriched phases were purified in order to obtain fuel-grade butanol-based biodiesel. Samples after removing of butanol under vacuum followed by water washing and drying were characterized by not enough high butyl esters content (about 94-95\%), as well as higher than allowed content of unconverted glycerides. Vacuum distillation as final purification step allowed fitting butyl esters samples composition within the requirements for biodiesel fuel. Distilled samples contained about $99 \%$ of butyl esters, 0.4-0.5\% of monoglycerides and almost no n-butanol, glycerol, di- and triglycerides. Oxidative treatment $\left(110^{\circ} \mathrm{C}, 6 \mathrm{~h}\right.$, air bubbling) revealed the high oxidation stability of the sample, originated from wasted high-oleic oil, due to the predominance of oleic acid in its fatty acid composition. The sample, obtained from refined sunflower oil (mainly linoleic acid in fatty acid composition), demonstrated very low stability. Addition of at least $2000 \mathrm{mg} / \mathrm{kg}$ of antioxidant 2,6-di-tert-butyl-4-methylphenol was shown to be able to improve this characteristic to the level of biodiesel requirements.

Keywords: fatty acid butyl esters, biodiesel, potassium butoxide, oxidation stability, antioxidant

\section{Introduction}

Biodiesel is alternative biomass-derived fuel for compression-ignition engines. About its production, utilization, advantages and disadvantages relative to traditional petroleum diesel many are told elsewhere [1-3]. Biodiesel is a mixture of long-chain fatty acids alkyl esters, which are usually produced via catalytic transesterification of both fresh and wasted vegetable oils or animal fats with corresponding monohydric alcohol. Only fatty acid methyl esters (FAME) have practical significance as biodiesel fuel. Methanol, used in FAME production, is known as the most toxic and dangerous among monohydric alcohols, but it is also the cheapest one. Besides that, since methanol is mainly produced from natural gas, FAME cannot be regarded as fully biorenewable fuel. Also, current $2021^{\text {th }}$ gas crisis in Europe may probably turns the manufacturers towards the diversification of alcohols feedstock, used in biodiesel production. Among most obvious alternatives for methanol are bioalcohols. After obvious ethanol, biobutanol ( $n$-butanol, obtained from biomass via biofermentative processes) is the best candidate. The main advantage of fatty acids butyl esters (FABE) comparing with FAME is sufficiently better cold flow properties [4], which makes them more valuable fuel under cold weather conditions. As for Ukraine, all the targets to develop the motor biofuels field (for instance, to produce yearly about 90 mln. tones of biodiesel till 2020 [5]) remained no more than declarations and there is still no biodiesel production or using. According to abovementioned, FAME production in Ukraine, having permanent problems with natural gas supply and no domestic methanol production, do not seem to have any real perspectives in close future.

The common way of biodiesel production via alkaline-catalyzed transesterification of triglycerides (TG) is far more complicated in case of methanol substitution with butanol. This is mainly due to the lower acidity and polarity of longer-chain monohydric alcohols comparing with methyl alcohol. Related issues are discussed in detail in previous works of our group $[6,7]$. There exists the problem with selfseparation of alkaline butanolysis products, as their mixture forms single phase unlike to the methanolysis process. Formation of separate glycerol layer, 
containing most of reaction glycerol and also catalyst, soaps and alcohol, is common for metanolysis. The absence of self-separation makes downstreaming processing of biodiesel more complicated.

There are enough examples of effective alkaline butanolysis of oils using both hydroxide [8, 9] and alkoxides catalysts [4, 9, 10]. In work [4] butanolysis of low-acidic rapeseed and wasted frying oil (0.05 and $0.07 \%$ of FFA - free fatty acids) was catalyzed by potassium methoxide and 93-96\% molar yields were achieved in synthesis under optimal reaction conditions (alchohol-to-oil molar ratio - 6:1, $1 \mathrm{~h} ; 70$ $75{ }^{\circ} \mathrm{C}$ and $1.2 \%$ of catalyst for wasted oil or $90{ }^{\circ} \mathrm{C}$ and $1.1-1.15 \%$ of catalyst for rapeseed oil). Reaction products separated after butanol removal by distillation, obtained butyl esters were washed. Final product contained $96.64 \%$ and $96.85 \%$ of FABE, which fulfills the requirements for biodiesel (at least $96.5 \%)$. In work [10] sodium butoxide, obtained by reaction of $\mathrm{Na}$ with alcohol, were used as catalyst of food grade soybean oil ( $<0.5 \%$ FFA) butanolysis. High molar yield of FABE was achieved in very short reaction time $(5 \mathrm{~min})$ without heating $\left(22{ }^{\circ} \mathrm{C}\right)$ using alcohol-to-oil molar ratio $6: 1$ and $0.66 \%$ of catalyst. Products remained in single phase; their separation was enforced by removing of butanol by vacuum distillation. Crude esters were purified via extraction by deep eutectic solvents (choline chloride with glycerol or ethylene glycol). Under certain purification conditions resulting FABE content was in biodiesel normative range. Effective catalysis of butanolysis by hydroxides needs higher alcohol excess and longer reaction time. In work [8] enough high oil conversion (rapeseed, about $1 \%$ of FFA) was achieved using 1215:1 alcohol-to-oil molar ratio, $1.2-1.5 \% \mathrm{KOH}$ at $30{ }^{\circ} \mathrm{C}$ or $80{ }^{\circ} \mathrm{C}$ after $2-4 \mathrm{~h}$. Separation of reaction products was enforced by neutralization (strong mineral acids or $\mathrm{CO}_{2}$ bubbling) followed by removing of alcohol by vacuum distillation. Neutralization by strong acids resulted in high acid value of butyl esters. In case of $\mathrm{CO}_{2}$ final mass yield of crude esters relative to initial oil was in range $80-100 \%$, while maximal theoretically possible mass yield of FABE is near 115 $\%$ on the oil basis. But these were not biodiesel yet, since the content of glycerol and soaps was higher then allowed. In the next paper of the same research group butanolysis of rapeseed oil (no properties specified) and separation of products using the same approach resulted in only 56-66\% mass yield of crude butyl esters relative to oil in case of $\mathrm{KOH}$ as catalyst and 79$89 \%$ in case of potassium tert-butoxide as catalyst. In previous works of our group [6, 7] the high efficiency of potassium $n$-butoxide catalytic solution, obtaining from $\mathrm{KOH}$ and $n$-butyl alcohol only in patent-pending way [11], was demonstrated. The high yields and glycerol layer separation were achieved under low excess of alcohol within short reaction time.
Stability is important criteria concerning any motor fuel properties. The stability of biodiesel is known to be one of the problem characteristic, it is always lower than stability of common mineral diesel fuel [12]. This is, obviously, due to the presence of the residues of unsaturated fatty acids, containing highly reactive olephinic bonds. The formation of deposits and gum, the darkening of fuel due to contaminants emergence, including alcohols, acids, aldehydes, peroxides etc. occurs in course of biodiesel storage [12-14]. The oxidative stability is one of the major issues for implementation the use of biodiesel as an alternative to petrodiesel fuel [12]. Oxidation is possible both during storage or directly in diesel engine fuel supply system. In modern diesel engines with high-pressure fuel pumping, the recirculating fuel may be heated to $60-150{ }^{\circ} \mathrm{C}$ and contact with hot air and, thus, can be partially oxidized [15-17]. There are the wide variety of biodiesel stability characterization techniques, including thermal stability (ASTM D646808), storage stability (ASTM D4625-16, ASTM D5304-15 and EN 15751) and oxidation stability tests (ASTM D2274, ASTM D7545-14, and EN 14112) [15]. The common normative standards for biodiesel fuel, such as European EN14214, set the requirements for oxidation stability at $110{ }^{\circ} \mathrm{C}$ (at least $6 \mathrm{~h}$ ), measuring by accelerated high-temperature oxidation methods (so-called Rancimat methods).

Oxidation of fatty acids esters forms peroxy radicals. It is initiated by free radical formation at the allylic position due to reaction with oxygen $[15,18]$. Formed peroxy radicals convert to hydroperoxides and alkyl radicals. The former may convert to hydroxyl and alkoxy radicals, which can decompose to alkyl aldehydes and alkyl radicals, to form acids in result of oxidation or to polymerize with other alkenes $[1,15$, 19-20]. Oxidation of biodiesel is difficult to avoid, the most effective method for its preventing includes special approaches for storing, excluding the air, light and high-temperature exposure etc. However, such conditions are difficult to achieve, and the most practically valuable methods is introduction of antioxidants, extending the oxidation induction period [12]. Chain breakers (peroxide radical quenchers) and hydroperoxide decomposers (reducing agents) are the most common antioxidants $[12,21]$. The major widely used synthetic antioxidants are butylated hydroxytoluene (BHT), butylated hydroxyanisole (BHA), tertbutylated hydroquinone (TBHQ), pyrogallol, i.e., 1,2,3-trihydroxybenzene (PY), and propylgallate, i.e., propyl 3,4,5-trihydroxybenzoate (PG) $[12,22]$.

The general aim of the present work was to obtain fuel quality butanol-based biodiesel. For such a purpose a number of tasks was completed: to carry out effective alkaline butanolysis of fresh and wasted frying sunflower oil based on earlier developed 
approaches, using potassium butoxide catalytic solution; to develop the purification method of reaction products; to test the oxidation stability of the latter and to prove the applicability of common synthetic antioxidant for enhancement of this characteristic of sunflower oil butyl esters.

\section{Materials and methods}

\section{Chemicals}

Refined frozen deodorized sunflower oil sample (DSTU 4492), having acid value (AV) $0.05 \mathrm{mg} \mathrm{KOH} / \mathrm{g}$ and water content $-0.05 \%$ ) was purchased from local market. Fatty acid composition was the following: palmitic acid (C16:0) - 7.0\%, stearic acid (C18:0) $3.7 \%$, oleic acid (C18:1) - $25.3 \%$, linoleic acid (C18:2) - 61.2\%, other fatty acids (FA) $-2.8 \%$. Wasted frying high-oleic sunflower oil sample (acid number $-1.20 \mathrm{mg} \mathrm{KOH} / \mathrm{g}$, water content $-0.05 \%$; 4.4\% C16:0, 2.6\% C18:0, 81.7\% C18:1, 6.1\% C18:2, $5.2 \%$ other FA) was kindly provided by local reseller. Fresh high-oleic sunflower oil was produced according TUU10.4-0033358-004:2016.

n-Butyl alcohol (Turkey, GC area assay $99.37 \%$, water content about $0.15 \%$ ), used as transesterification reagent, was technical grade. Analytical grade potassium hydroxide (Czech Republic, 83.0\% $\mathrm{KOH}$ according to titration of fresh reagent batch), technical rectified ethyl alcohol, reagent grade anhydrous $i$-propyl alcohol, synthetic zeolite KA-Y/3A (Russian Federation, dynamic water vapor capacity $-150 \mathrm{mg} / \mathrm{cm}^{3}$ ) as well as already mentioned $n$-butanol were used in preparation of potassium butoxide (KOBu) catalytic solutions. Also, technical grade sodium hydroxide (China, $99.8 \%$ $\mathrm{NaOH}$ ) was the reagent for synthesis of sodium butoxide for the analytical purposes. Anhydrous technical grade sodium sulfate was applied in drying of washed biodiesel.

Reagent grade methylpalmitate (gas chromatographic (GC) area assay - 98.65\%), pharmaceutical grade glycerol, reagent grade $n$ butanol, $\quad N$-Methyl- $N$-(trimethylsilyl) trifluoroacetamide (MSTFA, for GC derivatization), glyceryl tridecanoate ( $\geq 99 \%$, GC grade) and ASTM D6584 standard solution kit (5 pyridine solutions of 1monoolein, 1,3-diolein, triolein and glycerol of various concentration) were used in gas chromatographic analyses.

$0.1 \mathrm{~N} \mathrm{HCl}$ water solution (prepared from fixanale), as well as indicators bromophenol blue and phenolphthalein were used in acid-base titration.

2,6-Di-tert-butyl-4-methylphenol (also known as butylated hydroxytoluene - BHT) produced according TU 38.5901237-90 (Russian Federation) was used as antioxidant additive.

$\mathrm{N}, \mathrm{N}$-dimethylformamide (DMFA, 99.9\%), reagent grade $n$-hexane, analytic grade anhydrous pyridine and reagent grade $i$-propanol were used as solvents for the analytic purposes.

Gas chromatographic analyses were carried out using high pure helium and hydrogen gases. Technical purity argon gas was used in vacuum distillation of butyl esters.

\section{Synthetic and purification methods}

Potassium butoxide catalytic solution in $n$ butanol was obtained through the intermediate stage of potassium ethoxide synthesis from $\mathrm{KOH}$, dissolved in ethyl alcohol. Synthetic procedure consisted in repeated drying of ethanol-water azeotrope, condensed over zeolite KA in Soxhlet extractor, followed by returning of the dehydrated ethanol in reaction media. The method is described in detail in patent of Ukraine [23]. Thereafter, $n$-butanol was added to resulted ethoxide solution (1:1 by volume) and ethanol was removed by distillation with dephlegmator. Samples of $\mathrm{KOBu}$ solutions were also obtained in similar way from iso-propanol alkali solution.

Transesterification of oil samples was carried out in 0.51 conic flask with continuous stirring. At first, oil was put into reaction flask (100 g of refined oil or $200 \mathrm{~g}$ of wasted frying oil), then the predetermined masses of $\mathrm{KOBu}$ solution and $n$-butanol were quickly added and stirring was started (500 rpm, magnetic stirrer with triangular anchor). Amount of loaded alkaline catalyst is presented in $\%_{\text {eq. кон units }}$ relative to mass of oil. Maintaining of the lowerambient reaction temperature $\left(15^{\circ} \mathrm{C}\right)$ was provided by water bath, filled with chilled water. In course of syntheses dense non-fluent primary glycerol layer (GL) was deposited on the bottom of reaction flask. It remained there after transferring the reaction products into separation funnel, where additional amount of secondary glycerol layer settled during few next hours or overnight.

Obtained ester-enriched upper phases (ester layers - EL) after self-separation was subjected to successive purification steps. At the first step EL was placed in round bottom flask and butanol was removed by distillation under mild vacuum (waterjet pump, 3$4 \mathrm{kPa}$ ) and continuous stirring (500 rpm) with heating by water bath. The temperature of the latter was gradually increased from ambient to $90{ }^{\circ} \mathrm{C}$. Resulting mixture was transferred into separation funnel, where additional phase separation occurred. The upper of two obtained phases was repeatedly washed with hot tap water $\left(60-80{ }^{\circ} \mathrm{C}, 1: 1\right.$ by volume each time) until formation of clear water layer with neutral $\mathrm{pH}$ (5-7 successive washing steps). Washed butyl esters were dried over anhydrous sodium sulfate. Thereafter one half of washed samples were subjected to batch vacuum distillation $(\sim 0.1-0.3 \mathrm{kPa})$ under continuous bubbling of argon gas. Heating was provided by oil bath $\left(190-260{ }^{\circ} \mathrm{C}\right)$, butyl esters fraction condensed in temperature range $170-230{ }^{\circ} \mathrm{C}$. 
The block-scheme of whole process of FABE production and purification is given in the Fig. 1. $\mathrm{KOBu}$ preparation is presented by example, which includes the initial stage of ethoxide preparation from
$\mathrm{KOH}$ solution in ethanol. The scheme would be the same also in the case of iso-propanol alkali solution utilization on the first stage.

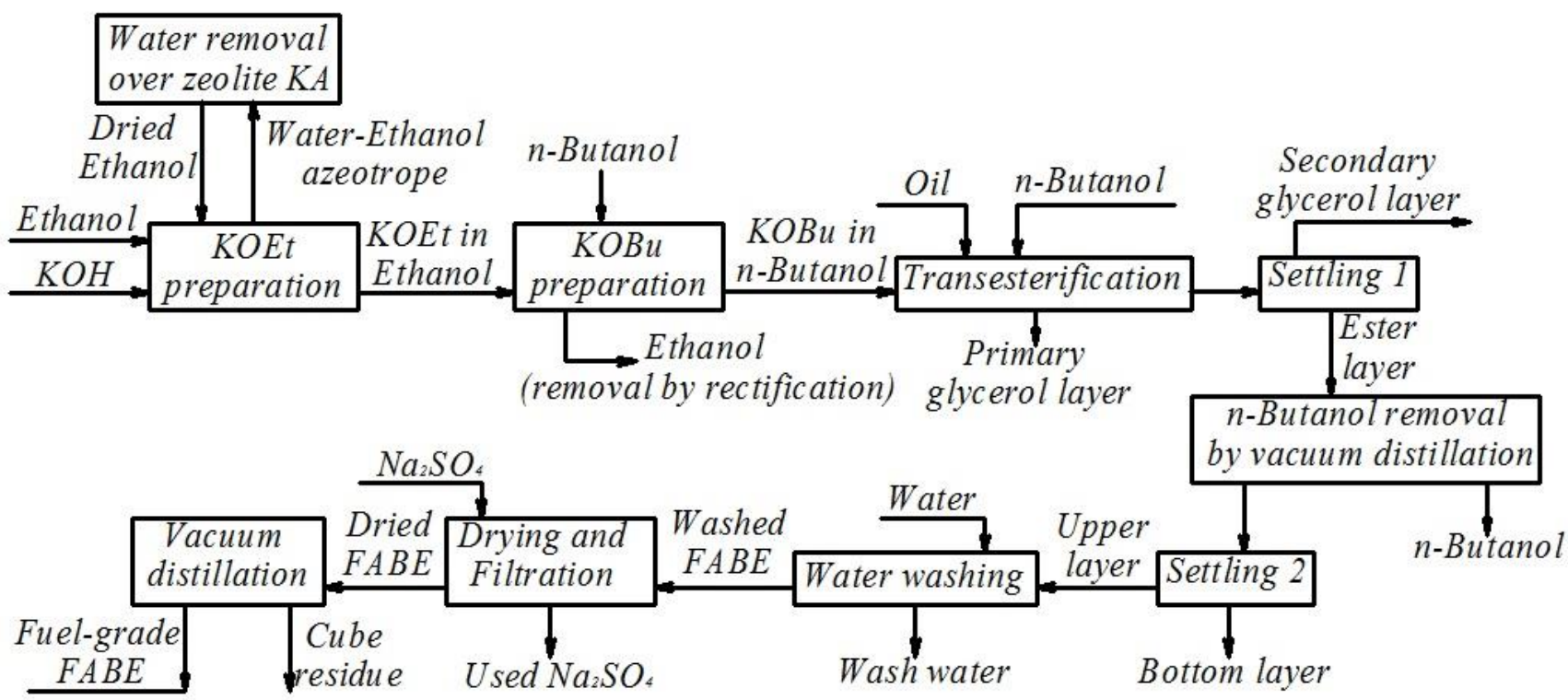

Fig.1. Block-scheme of the lab-scale process of FABE production.

\section{Indicators of efficiency of the butanolysis process}

The main indicator of the efficiency of the oil transesterification was the effective molar yield of butyl esters $\mathrm{Y}_{\mathrm{ef}}(\%)$ in composition of ester layer:

$$
\mathrm{Y}_{\mathrm{ef}}=\frac{\mathrm{C}_{\mathrm{FABE}} \cdot \mathrm{m}_{\mathrm{EL}} \cdot \mathrm{M}_{\mathrm{oil}}}{3 \cdot\left(\mathrm{m}_{\mathrm{oil}}-\mathrm{m}_{\mathrm{FFA}}\right) \cdot \mathrm{M}_{\mathrm{FABE}}},
$$

where $\mathrm{C}_{\mathrm{FABE}}$ is concentration (\%) of butyl esters in ester layer after phase separation; $\mathrm{m}_{\mathrm{EL}}, \mathrm{m}_{\mathrm{oil}}, \mathrm{m}_{\mathrm{FFA}}$ are masses (g) of ester layer, oil and free fatty acids in oil; $\mathrm{M}_{\text {oil }}, \mathrm{M}_{\mathrm{FABE}}$ are molar masses $(\mathrm{g} / \mathrm{mol})$ of oil triglycerides and butyl esters, averaged according to the fatty acid composition. Term «effective yield» implies the taking into account only the FABE in composition of ester layer, since in general case some fraction of esters may also transfer into glycerol layer.

Also, the mass yields of EL or purified esters relative to initial oil was calculated:

$$
\mathrm{Y}_{\text {mass }}=\frac{\mathrm{m}_{\text {prod }}}{\mathrm{m}_{\text {oil }}} \cdot 100 \%,
$$

where $\mathrm{m}_{\text {prod }}$ is mass $(\mathrm{g})$ of ester layer or purified FABE.

The fraction $(\%)$ of the alkaline catalyst, which remains in composition of ester or glycerol layer or transforms into soaps, from its loaded amount was calculated as follows:

$$
\text { Fraction from loading }=\frac{\mathrm{C}_{\mathrm{x}} \cdot \mathrm{m}_{\text {layer }}}{\mathrm{n}_{\text {cat }} \cdot \mathrm{m}_{\text {oil }}} \cdot 100 \% \text {, }
$$

where $\mathrm{C}_{\mathrm{x}}$ is content ( $\left.\%_{\text {eq.KOH}}\right)$ of catalyst or soaps, calculated as $\mathrm{KOH}$; $\mathrm{m}_{\text {layer }}$ is mass $(\mathrm{g})$ of ester or glycerol layer; $\mathrm{n}_{\text {cat }}$ is amount ( $\left.\%_{\text {eq.KOH}}\right)$ of loaded catalyst, calculated as $\mathrm{KOH}$, relative to mass of oil.

\section{Oxidation stability determination}

Samples of distilled butyl esters, containing 500, 1000,1500 and $2000 \mathrm{mg} / \mathrm{kg}$ BHT antioxidant, were prepared by simple mixing with magnetic stirrer. $5.0 \mathrm{~g}$ of the sample (containing antioxidant or not) was placed into the sealed tube and bubbled with atmospheric air $\left(300 \mathrm{~cm}^{3} / \mathrm{min}\right)$ under continuous heating $\left(110^{\circ} \mathrm{C}\right.$, oil bath) for $6 \mathrm{~h}$. Such a treatment procedure is the same as in the standard EN14112 Rancimat method. But instead of the determination of oxidation induction period by measuring the conductivity changes, samples of treated butyl esters were subjected to GC analysis and also titrated to determine the acid value. In separate case, the samples for GC analysis were also taken directly in course of oxidative treatment. If composition of the sample did not undergo considerable alterations and remained in the range of the biodiesel normative requirements, it was regarded as meeting the requirements for antioxidant stability.

\section{Gas chromatography methods}

Butyl esters samples composition was analyzed using Agilent 7890A Series gas chromatograph equipped with split/splitless (SS) and cool-on-column (COC) inlets, flame-ionization detector (FID) and J\&W HP-5 (30 m, $0.32 \mathrm{~mm}, 0.25 \mu \mathrm{m})$ and DB-5HT $(15 \mathrm{~m}, 0.32 \mathrm{~mm}, 0.1 \mu \mathrm{m})$ capillary columns with $((5 \%$ phenyl)-methyl polysiloxane stationary phase. Highpurity helium was used as carrier gas. 
FABE content was measured by modified method based on standard method of determination of methyl esters in biodiesel EN14103. Methyl palmitate (MP) was used as internal standard instead of methyl heptadecanoate. Sample $(0.15-0.20 \mathrm{~g})$ and standard (about $0.02 \mathrm{~g}$ ) were weighted with analytic accuracy and dissolved in $5 \mathrm{~cm}^{3}$ of $n$-hexane. At least two of such probes were taken for each FABE sample, each of them were analyzed twice. Analyses were carried out under following chromatographic conditions: SS inlet temperature $-250{ }^{\circ} \mathrm{C}$; constant pressure mode (82.7 kPa); split ratio 36:1; column (HP-5) temperature $210{ }^{\circ} \mathrm{C} / 27 \mathrm{~min}, 5\left({ }^{\circ} \mathrm{C} / \mathrm{min}\right) / \mathrm{min}$ up to $320{ }^{\circ} \mathrm{C}$, $280^{\circ} \mathrm{C} / 10 \mathrm{~min}$; FID temperature $250^{\circ} \mathrm{C}$. This method also was applied to measure the changes in content of butyl esters of major fatty acids (C16:0, C18:0, C18:1, $\mathrm{C} 18: 2)$ as well as to monitor the BHT antioxidant consumption in oxidation stability studies.

Monoglycerides (MG), diglycerides (DG) and TG concentrations were determined by means of derivatization with MSTFA followed by chromatographic analyses (DB-5HT column with 1 $\mathrm{m} / 0.53 \mathrm{~mm}$ fused silica retention gap, COC inlet) with tricaprin as internal standard according ASTMD 6584 standard method. Original ASTMD 6584 method involves also determination of free glycerol with 1,2,4butanetriol as standard, but its delivery in Ukraine is prohibited. About $0.1 \mathrm{~g}$ of FABE sample was weighted with analytic accuracy in $10 \mathrm{~cm}^{3}$ vial, then tricaprin solution in pyridine $\left(200 \mu \mathrm{l}, 4000 \mu \mathrm{g} / \mathrm{cm}^{3}\right)$ and MSTFA $(100 \mu \mathrm{l})$ were added. Vial was sealed, shaken, and left for $20 \mathrm{~min}$ at ambient temperature. Then its content was dissolved in $8 \mathrm{~cm}^{3}$ of $n$-hexane and chromatographic analysis was carried out under conditions described in [24]. MG, DG and TG content was calculated from calibration, which was built using ASTM D6584 standard solution kit.

For measurement of low glycerol concentrations separate analysis was set up. About $0.1 \mathrm{~g}$ of FABE sample was weighted with analytic accuracy in $4 \mathrm{~cm}^{3}$ vial followed by addition of $200 \mu \mathrm{l}$ of pyridine and $100 \mu \mathrm{l}$ of MSTFA. Vial was sealed, shaken and left for $20 \mathrm{~min}$ at ambient temperature, then $3 \mathrm{~cm}^{3}$ of $n$-hexane was added. Resulting solution was analyzed under such conditions: SS inlet temperature $-300{ }^{\circ} \mathrm{C}$; constant flow mode $\left(3 \mathrm{~cm}^{3} / \mathrm{min}\right)$; split ratio $36: 1$; column (HP-5) temperature $110{ }^{\circ} \mathrm{C} / 7 \mathrm{~min}, 30{ }^{\circ} \mathrm{C} / \mathrm{min}$ up to $320^{\circ} \mathrm{C}, 320^{\circ} \mathrm{C} / 15 \mathrm{~min}$; FID temperature $300{ }^{\circ} \mathrm{C}$. Concentration of glycerol was calculated from previously built calibration line.

Concentration of butanol was measured in another chromatographic analysis. $0.6 \mathrm{~cm}^{3}$ of the FABE sample was weighted in $10 \mathrm{~cm}^{3}$ vial and dissolved in $5 \mathrm{~cm}^{3}$ of DMFA, containing $0.230 \%$ MP as internal standard. This solution was also used to estimate the glycerol concentration higher than $0.5 \%$ in EL (without derivatization), using the same MP in role of standard. Analyses was carried out under following conditions: SS inlet temperature $-300{ }^{\circ} \mathrm{C}$; constant flow mode $\left(3 \mathrm{~cm}^{3} / \mathrm{min}\right.$ for $9 \mathrm{~min}, 3\left(\mathrm{~cm}^{3} / \mathrm{min}\right) / \mathrm{min}$ up to $9 \mathrm{~cm}^{3} / \mathrm{min}$ and $9 \mathrm{~cm}^{3} / \mathrm{min}$ to the end of analysis); split ratio 20:1; column (HP-5) temperature $35{ }^{\circ} \mathrm{C} / 9 \mathrm{~min}, 10^{\circ} \mathrm{C} / \mathrm{min}$ up to $80{ }^{\circ} \mathrm{C}, 80{ }^{\circ} \mathrm{C} / 1 \mathrm{~min}$, $5{ }^{\circ} \mathrm{C} / \mathrm{min}$ up to $320{ }^{\circ} \mathrm{C}, 320{ }^{\circ} \mathrm{C} / 7.5 \mathrm{~min}$; FID temperature $300{ }^{\circ} \mathrm{C}$. $n$-Butanol and glycerol concentration were calculated relative to MP peak area using previously built calibrations.

Another analytic methods

Acid value (AV) of oils and purified butyl esters was measured by means of titration with sodium butoxide solution in $n$-butanol with indicator bromothymol blue as described in [25]. Alkaline catalyst and soaps content in the butanolysis products were determined by two-step acid-base titration method as described in [26]. Alkali was determined in a first titration step, using $\mathrm{HCl} 0.1 \mathrm{~N}$ solution as titrant, iso-propanol as solvent and phenolphthalein as indicator. In a second titration step, the soap content was determined using the same titrant and bromophenol blue as indicator.

Water content in oils samples was determined by heterogenic azeotrope distillation using benzene to form heterogeneous azeotrope with water (Dean-Stark method). Density of butyl esters samples was measured at $15{ }^{\circ} \mathrm{C}$ by means of areometers according to EN ISO 3675. Kinematic viscosity (KV) of FABE was determined at $40{ }^{\circ} \mathrm{C}$ as described in EN ISO 3104 using glass capillary viscometer.

\section{Results and discussions}

\section{FABE synthesis}

Butanolysis of refined sunflower oil was carried using 3 samples of KOBu catalytic solutions, prepared both from $\mathrm{KOH}$ solution in ethanol $(\mathrm{KOBu}(\mathrm{Et}))$ and iso-propanol $(\mathrm{KOBu}(\mathrm{iPr} 1)$ and $\mathrm{KOBu}(\mathrm{iPr} 2))$. Though such method of the butoxide synthesis required additional reagents (ethanol or iso-propanol) and molecular sieves, it is less time-consuming and energyconsuming comparing with the earlier used method $[6,7,11]$ based on the azeotropic distillation of alkali metal hydroxide solution in $n$-butanol. Results of experiments on transesterification of the refined oil sample under the same reaction conditions are given in Table 1 (samples BRSO-1, BRSO-2 and BRSO-3, $\mathrm{t}=$ $\left.15^{\circ} \mathrm{C}\right)$. Such reaction parameters were chosen on the base of previous studies $[6,7]$ as providing both high yield of butyl esters and effective phase separation. In all three experiments at the same reaction conditions, but using three different samples of KOBu catalytic solutions, the very close results were obtained. Namely, in all syntheses both high FABE yield (9394\%) and removing of vast majority of glycerol and alkaline catalyst into separate phase were achieved. Obtained results demonstrated the good reproducibility 
of the $\mathrm{KOBu}$ preparation methods, using different alcohols (ethanol or iso-propanol), as well as reproducibility of $\mathrm{KOBu}$ parallel synthesis in case of the same iso-propanol $(\mathrm{KOBu}(\mathrm{iPr} 1)$ and $\mathrm{KOBu}(\mathrm{iPr} 2)$ samples). In case of wasted oil butanolysis (BWFO-1) slightly higher excess of butanol was used, process was carried out for additional $10 \mathrm{~min}$. Also, additional $\mathrm{KOBu}$ was included for FFA neutralization. As result, even higher butyl esters yield was achieved, however ester layer contained more glycerol and potassium. The latter was almost exclusively in composition of soaps, as was revealed by acid-base titration with two indicators. Less effective phase separation of BWFO-1 synthesis product is most likely due to the presence of FFA in wasted oil, but also higher alcohol-to-oil ratio and longer reaction time may have some impact.

Table 1. Conditions and results of the experiments on transesterification of oil samples $\left(t=15^{\circ} \mathbf{C}\right)$

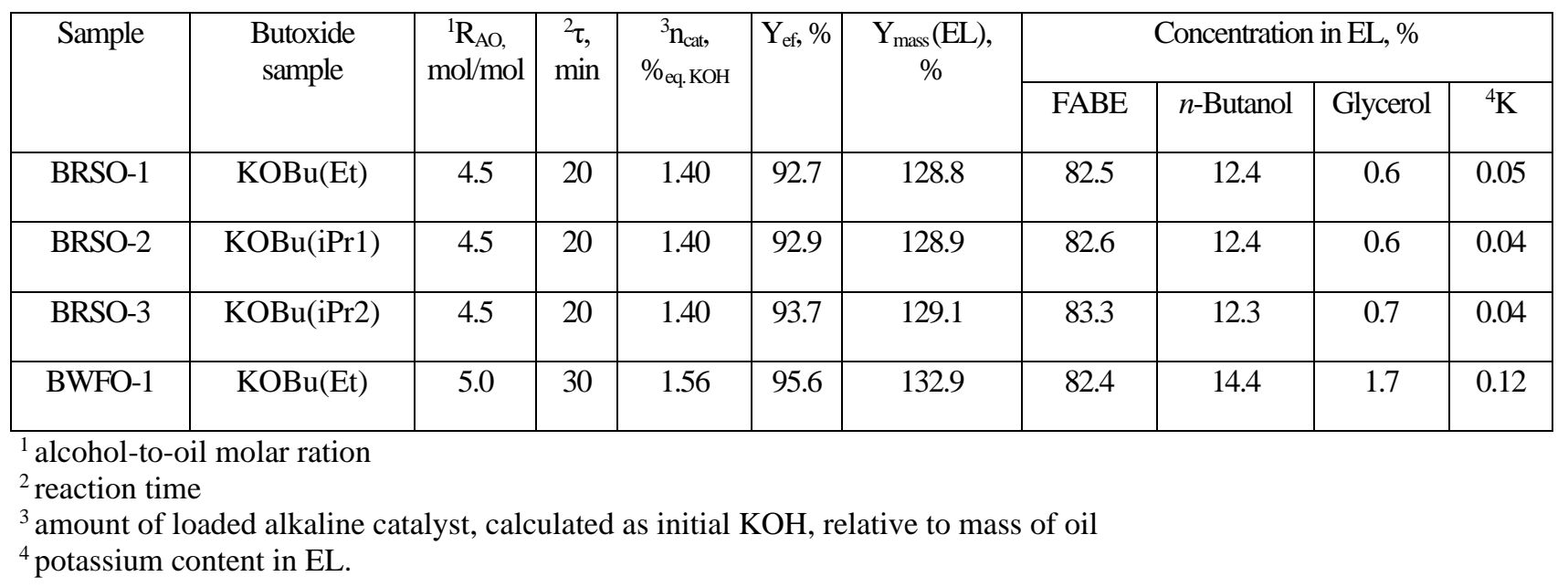

Distribution of alkaline catalyst between the layers of reaction products and its deactivation due to saponification reactions (both of acylglycerides and butyl esters) need separate attention to pay. Previous studies of our research group [6,7] revealed the total difference of the compostion of glycerol layers, formed during alkaline butanolysis, comparing with that formed in more common processes of oils transesterification with methyl or ethyl alcohols. In the latter cases glycerol layers contain beside glycerol also the significant fraction of esters and alcohol, some unconverted acylglycerides as well as soaps and alkaline catalyst in different proportions. On the contrary, the GL of butanolysis is composed almost exclusively of neat glycerol and alkali. Such observations were never earlier reported in literature sources.

Data of the Table 2 show the distribution of the alkali and soaps between ester layers and primary glycerol layers after refined oil butanolysis. All ester layers contain no alkaline catalyst and only minor amount of soaps. Vast majority of loaded catalyst transfer into the primary GL (settled during synthesis), whereas soaps are presented in very limited quantities. The amount of primary GL the latter was 7.4-7.6\% from oil mass, besides that 2.2-2.6\% of secondary GL of close nature formed during settling. It worth be mentioned, that the maximal possible amount of GL, containing only glycerol and alkali, in case of full oil conversion is about $11 \%$ from oil mass.

Table 2. Distribution of alkaline catalyst and soaps in refined sunflower oil butanolysis products

\begin{tabular}{|c|c|c|c|c|c|c|c|c|}
\hline \multirow{2}{*}{ Sample } & \multicolumn{4}{|c|}{ Ester layer } & \multicolumn{4}{c|}{ Primary glycerol layer } \\
\cline { 2 - 9 } & \multicolumn{2}{|c|}{ Catalyst } & \multicolumn{2}{|c|}{ Soaps } & \multicolumn{2}{c|}{ Catalyst } & \multicolumn{2}{c|}{ Soaps } \\
\hline & $\begin{array}{c}\text { Content, } \\
\%_{\text {eq. KOH }}\end{array}$ & $\begin{array}{c}\text { Fraction from } \\
\text { loading, } \%\end{array}$ & $\begin{array}{c}\text { Content, } \\
\%_{\text {eq. KOH }}\end{array}$ & $\begin{array}{c}\text { Fraction from } \\
\text { loading, } \%\end{array}$ & $\begin{array}{c}\text { Content, } \\
\%_{\text {eq. KOH }}\end{array}$ & $\begin{array}{c}\text { Fraction from } \\
\text { loading, } \%\end{array}$ & $\begin{array}{c}\text { Content, } \\
\%\end{array}$ & $\begin{array}{c}\text { Fract } \text { KOH } \\
\text { loading, } \%\end{array}$ \\
\hline BRSO-1 & 0 & 0 & 0.069 & 6.3 & 13.71 & 72.6 & 0.71 & 3.8 \\
\hline BRSO-2 & 0 & 0 & 0.063 & 5.6 & 13.89 & 74.8 & 0.42 & 2.3 \\
\hline BRSO-3 & 0 & 0 & 0.064 & 5.9 & 14.07 & 75.8 & 0.38 & 2.0 \\
\hline
\end{tabular}

The transfer of major part of the catalyst into GL in course of synthesis from one point of view mostly prevents the saponification. Soaps formation leads to the conversion decrease and difficulties with 
separation and purification of esters. At the same time, the catalyst concentration decreases fast due to its removing into separate phase. Such the details are discussed in [7], where also the transformation of $\mathrm{KOBu}$ into potassium glyceroxide in course of transesterification was grounded. More likely, the alkali in GL composition is presented by glyceroxide, which is known as effective transesterification catalyst [27]. So, preserving the major part of alkaline catalyst after butanolysis in mixture with glycerol opens prospects for its reuse in transesterification or for another purposes.

Isolation of biodiesel-grade butyl esters.

In Table 3 the composition and some properties of butyl esters samples after different steps of purification are compared with requirements of European standard for methanol-based biodiesel. "W" in the end of the samples name refers to butyl esters after alcohol removal, washing with water and drying, while " $\mathrm{D}$ " means the distilled butyl esters. Carrying out the water washing of EL after butanolysis is strongly complicated by $n$-butanol with water partial miscibility. So, the prior butanol removing by distillation is needed, which also provides its recycling in the process. Products of refined oil transesterification were mixed together and then purified. FABE content after washing in BRSOW sample was a bit lower, than EN 14214 required, which mainly due to the presence of unconverted glycerides. For such cases the higher conversion of oil in synthesis will provide both increasing the FABE and decreasing the MG, DG and TG concentrations. This is easy achievable by increasing alcohol-to-oil molar ratio up to about 5.0-6.0. This also may decrease to some extent the fullness of phase separation, however this is may be the serious problem in case of highacidic low-grade oils, but not refined ones.

Table 3. Comparison of composition and physica-chemical properties of purified FABE samples versus normative requirements

\begin{tabular}{|c|c|c|c|c|c|c|c|c|c|c|}
\hline Sample & \multicolumn{5}{|c|}{ Concentration of components, $\%$} & $\begin{array}{c}\mathrm{AV}, \\
\mathrm{mg} \mathrm{KOH} / \mathrm{g}\end{array}$ & $\begin{array}{c}\mathrm{KV} \\
\left(40^{\circ} \mathrm{C}\right), \\
\mathrm{mm}^{2} / \mathrm{s}\end{array}$ & $\begin{array}{c}\text { Density } \\
\left(15^{\circ} \mathrm{C}\right), \\
\mathrm{kg} / \mathrm{m}^{3}\end{array}$ & $\begin{array}{c}\mathrm{Y}_{\text {mass }}, \\
\%\end{array}$ \\
\cline { 2 - 12 } & FABE & $n$-Butanol & Glycerol & MG & DG & TG & & & & \\
\hline BRSOW & 95.0 & 0.11 & 0.041 & 1.59 & 1.04 & 0.33 & 0.28 & 5.65 & 877 & 93.1 \\
\hline BRSOD & 98.9 & 0.04 & 0.017 & 0.45 & 0.01 & 0.00 & 0.26 & 5.13 & 873 & 86.1 \\
\hline BWFOW & 93.7 & 0.28 & 0.002 & 0.84 & 0.23 & 0.04 & 0.10 & 5.90 & 869 & 93.5 \\
\hline BWFOD & 98.9 & 0.02 & 0.005 & 0.39 & 0.01 & 0.00 & 0.12 & 5.68 & 868 & 89.4 \\
\hline${ }^{1}$ EN 14214 & $\begin{array}{c}96.5 \\
(\min )\end{array}$ & $\begin{array}{c}0.20 \\
(\max )\end{array}$ & $\begin{array}{c}0.02 \\
(\max )\end{array}$ & $\begin{array}{c}0.70 \\
(\max )\end{array}$ & $\begin{array}{c}0.20 \\
(\max )\end{array}$ & $\begin{array}{c}0.20 \\
(\max )\end{array}$ & $\begin{array}{c}0.50 \\
(\max )\end{array}$ & $3.5-5$ & $860-900$ & - \\
\hline
\end{tabular}

${ }^{1}$ Requirements of EN14214 standard for FAME as BD

Sample of washed esters from wasted oil BWFOW had other features of composition. Nonetheless some higher conversion, resulting in lower glycerides content, FABE concentration appeared to be lower than in BRSOW sample. This is more likely due to the presence of so-called polar compounds in wasted oil samples, which includes oligomerized or polymerized cross-linked triglycerides, yielding in transesterification heavy oligomeric esters. The presence of such compounds is known problem, which complicates the achieving target $96.5 \%$ ester content in wasted oil derived biodiesel $[28,29]$. Some excess content of the alcohol in BWFOW sample is a result of not enough full washing, as well as glycerol content in BWFOD sample. At the same time, water washing is almost ineffective for removal of MG, DG and TG.

Vacuum distillation of both samples improved the FABE, MG and DG concentrations, fitting them within EN 14214 requirements. Moreover, DG and TG are almost absent in distilled samples composition. Contents of glycerol and butanol were also within acceptable limits. As for the kinematic viscosity, it also decreased after distillation, but remained higher than 5 $\mathrm{mm}^{2} / \mathrm{s}$. Such KV values is intrinsic property of FABE due to the longer alcohol moiety in their molecules compared with methyl esters. The difference in KV between BRSOD and BWFOD samples is more likely caused by their fatty acid composition. It worth emphasizing, that relatively high FABE viscosity is not critical for their utilization like biodiesel, as some national standard, for example ASTM D6751 (USA), allows higher biodiesel $\mathrm{KV}$ (up to $6.0 \mathrm{~mm}^{2} / \mathrm{s}$ ).

Optimization of purified FABE yield was not the task in the current study. Let us reminded, that theoretically possible butyl esters mass yield from pure TG is near $115 \%$. Mass yield of final biodiesel can be sufficiently improved by reducing product losses in 
intermediate purification steps. For instance, the drying over $\mathrm{Na}_{2} \mathrm{SO}_{4}$ resulted in up to $10 \%$ product losses. Such stage should not be incorporated in a large production scale, instead of its drying under vacuum is more rational to use. However, in case of further vacuum distillation, drying stage is not needed. It is also possible to refuse from washing step and to carry out distillation of FABE after butanol removal. However, in this case the problems with glycerol content in distillate may arise. It can be resolved by dry washing step, coupled with vacuum distillation, which can be realized by condensation of FABE fraction over the layer of proper adsorbent. This also may purify the distillate from another relatively light polar compounds, possibly forming at high temperatures.

Separate attention should be paid to some nonfat admixtures, which may originate from initial oil. Composition of refined oil, mentioned by manufacturer, included only TG $(99.9 \%)$, while the composition of fresh high-oleic oil beside actual deodorized frozen oil also included additives E320 (antioxidant BHA - butylated hydroxyanisole) and E900 (defoamer polydimethylsiloxane) in unspecified amounts. The latter surely should not be present in biodiesel composition. It cannot be removed by water washing, but it also cannot be distilled and thus remained in composition of cube residue.

Oxidative stability of butanol-based biodiesel

Oxidative treatment of distilled butyl esters revealed the totally different oxidative stability of BRSOD and BWFOD samples. The former, containing mostly C18:2 fatty acid residues underwent severe degradation after $6 \mathrm{~h}$ airs bubbling at $110{ }^{\circ} \mathrm{C}$. The concentration of FABE decreased strongly (Fig. 2a), while oxidation products appeared in the composition of the treated sample (Fig. 2b). Acid value also increased many times (Fig. 2d). Addition of BHT antioxidant in BRSOD sample decreased the degradation rate, its concentration $2000 \mathrm{mg} / \mathrm{kg}$ appeared to be enough to protect the sample from chemical changes. Only at this highest antioxidant content, some relatively significant amount of BHT (about $350 \mathrm{mg} / \mathrm{kg}$ ) remained in the composition of the sample (Fig. 2c). In other cases, BHT additive was totally consumed in course of oxidation. As for the sample BWFOD, which fatty acid composition are predominantly presented by monounsaturated oleic acid, no any changes of its composition were observed even without antioxidant addition.
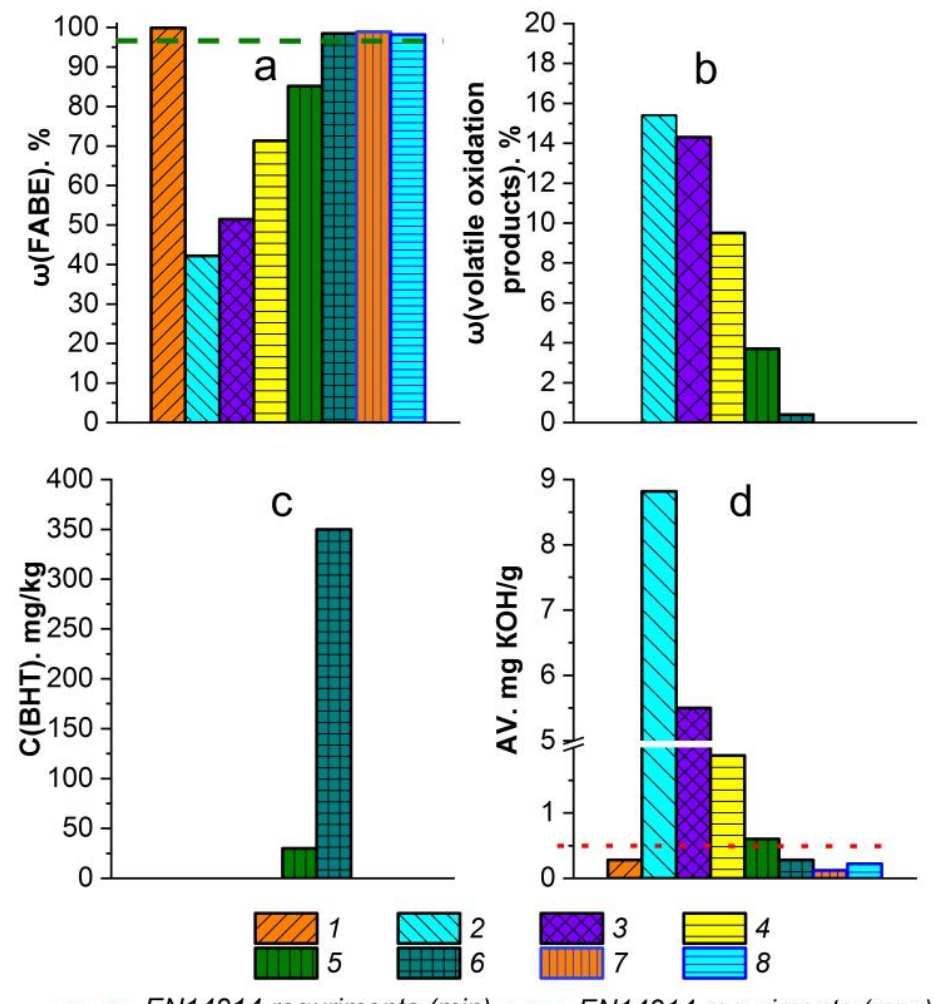

- - EN14214 requriments ( $\mathrm{min})$ - - EN14214 requriments (max)

Fig. 2. Content of FABE (a), volatile oxidation products (b) and antioxidant (c) in butyl esters samples and their acid value (d): 1 - initial BRSOD; 2 - oxidized BRSOD; 3 - oxidized BRSOD + $500 \mathrm{mg} / \mathrm{kg}$ BHT; 4 - oxidized BRSOD + $1000 \mathrm{mg} / \mathrm{kg}$ BHT; 5 - oxidized BRSOD + $1500 \mathrm{mg} / \mathrm{kg}$ BHT; 6 - oxidized BRSOD + $2000 \mathrm{mg} / \mathrm{kg}$ BHT; 7 - initial BWFOD; 8 - oxidized BWFOD.

Chromatograms of the initial and threated BWFOD samples (Fig. 3a) are totally identical and contain the same peaks, having the same relative intensities comparing with internal standard MP (retention time about $6 \mathrm{~min}$ ). The chromatogram of BRSOD sample after $6 \mathrm{~h}$ treatment without antioxidant 
(Fig. 3b) contains, besides peaks of butyl esters of main fatty acids (C16:0 near 6 min, C18:1 and C18:2 in range near 18-19 min and C18:0 near $20 \mathrm{~min}$ ), a wide variety of oxidation products signals. Among them there is a set of peaks of light oxidation products (in range about 2.5-8 $\mathrm{min}$ and $13-15 \mathrm{~min}$ ), as well as peaks, corresponding to oxidized FABE of C18 unsaturated fatty acids (in range about 28-38 min) and containing the same number of carbon atoms. All such compounds are referred as «volatile oxidized products» in Fig. 2b, while FABE content (Fig. 2a) takes into account only peaks of component, which are presented both on the initial and oxidized BRSOD sample chromatograms. The same signals were presented in chromatograms of oxidized BRSOD sample, containing 500-1500 mg/kg BHT. The higher was the antioxidant concentration, the lower was the fraction of oxidation products. As for the sample, containing $2000 \mathrm{mg} / \mathrm{kg}$ of antioxidant, its chromatograms almost did not change comparing with initial BRSOD and FABE content and AV remained in the range of biodiesel normative. It is worth emphasizing, that the total concentration of FABE and volatile oxidation products was substantially lower than FABE concentration before treatment and no other signals were presented on the chromatograms. This is the evidence of the presence of heavier nonvolatile oligomeric components, formed in course of oxidative treatment. Such components cannot be revealed via gas chromatographic analyses, and believed to be of the similar nature as oligomeric or dimeric esters, which are presented in wasted oils transesterification products and complicates the achievement of target $96.5 \%$ ester content in wasted oil based biodiesel [28]. However, the long-chain FFA are not determined under the used conditions of chromatographic analysis also.
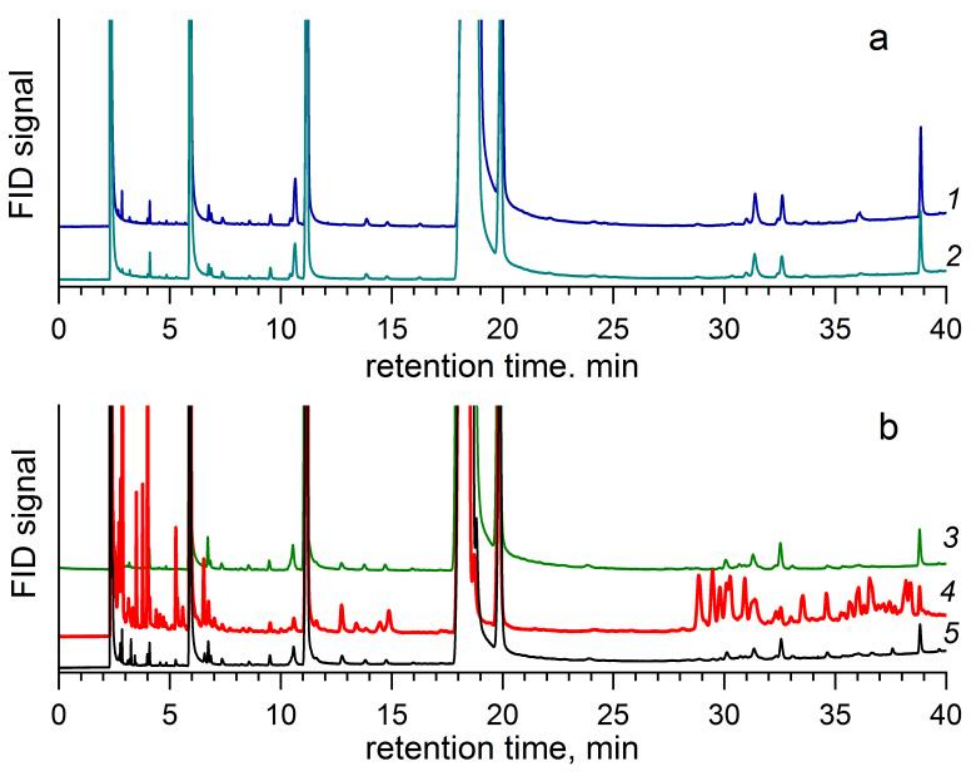

Fig. 3. Chromatograms of butyl esters samples before and after oxidative treatment $(6 \mathrm{~h}): 1-$ initial BWFOD; 2 - oxidized BWFOD; 3 - initial BWFOD; 4 - oxidized BWFOD; 5 - oxidized BWFOD + $2000 \mathrm{mg} / \mathrm{kg}$ BHT.

Changing of individual fatty acids esters concentration in result of oxidation treatment are presented in the Fig. 4. As clearly seen from given data, predominantly esters of diunsaturated linoleic acid underwent the degradation. Their concentration decreased by about 5 times (Fig. 4d), while lowering of the oleic acid esters content did not exceed one quarter from initial content (Fig. 4c). The decreasing of saturated fatty acids esters content was even less significant. The same trend was observed in the course of oxidation of BRSOD sample, containing $1000 \mathrm{mg} / \mathrm{kg}$ of antioxidant (Fig. 5). FABE content began to decrease (predominantly due to C18:2 esters) after vast majority of antioxidant consuming in course of first $4 \mathrm{~h}$ of treatment (Fig. 6).
It is interesting, that the concentration of $\mathrm{C} 18: 2$ ester in BWFOD sample, originated from high-oleic oil, remained unchanged, most likely, due to their insignificant content (about only 6\%). The excellent oxidation stability of the BWFOD sample is obviously due to the domination of many times more stable C18:1 (about 82\%) ester in its composition. However, the presence of the antioxidants in the composition of initial high-oleic sunflower oil may have separate influence on the stability of discussed sample. Tocopherols (vitamin E) are known as the most powerful natural-occurring fat-soluble antioxidant [30], their content and isomeric composition have significant impact on the oxidative stability of vegetable oils, including high-oleic sunflower oil [31]. 

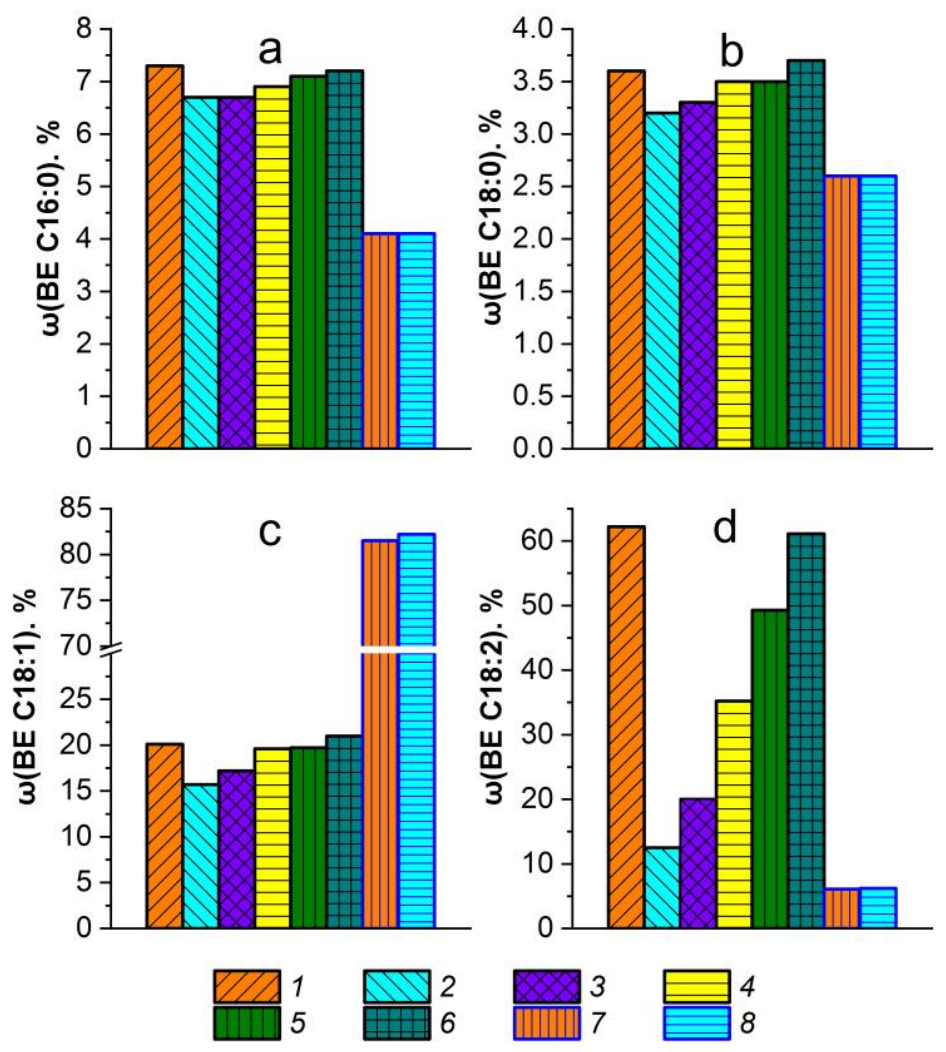

Fig. 4. Content of esters of palmitic (a), stearic (b), oleic (c) and linoleic (d) fatty acids in butyl esters samples: 1 - initial BRSOD; 2 - oxidized BRSOD; 3 - oxidized BRSOD + $500 \mathrm{mg} / \mathrm{kg}$ BHT; 4 - oxidized BRSOD + 1000 $\mathrm{mg} / \mathrm{kg}$ BHT; 5 - oxidized BRSOD + $1500 \mathrm{mg} / \mathrm{kg}$ BHT; 6 - oxidized BRSOD + $2000 \mathrm{mg} / \mathrm{kg}$ BHT; 7 - initial BWFOD; 8 - oxidized BWFOD.

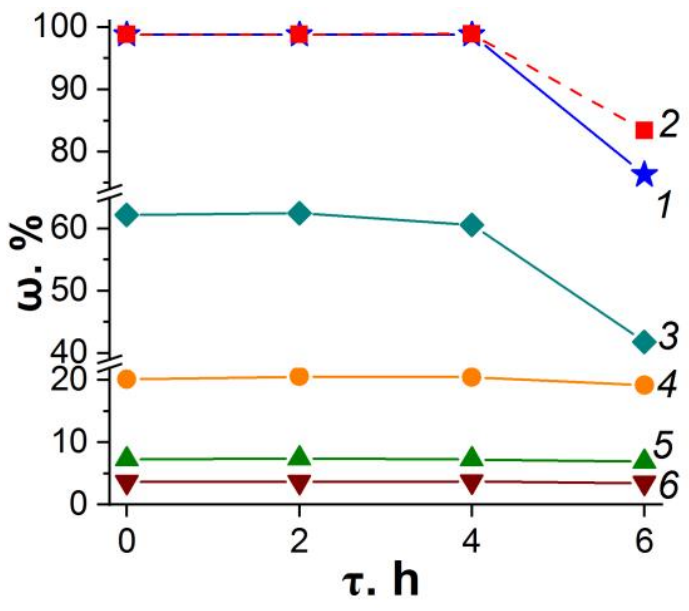

Fig. 5. Changing of the content of FABE (1), FABE and volatile oxidation products content (2), C18:2 esters (3), C18:1 esters (4), C18:0 esters (5) and C16:0 esters (6) in BRSOD sample with $1000 \mathrm{mg} / \mathrm{kg}$ BHT concentration in course of oxidative treatment.

However, the stability of the high-oleic sunflower oil was shown to be primarily influenced by its linoleic acid content. Its value lower than $10 \%$ provided excellent frying stability of oil, while C18:2 content higher than named value may be too high to achieve comparably high performance of oil during frying [31]. The close trend should be preserved also

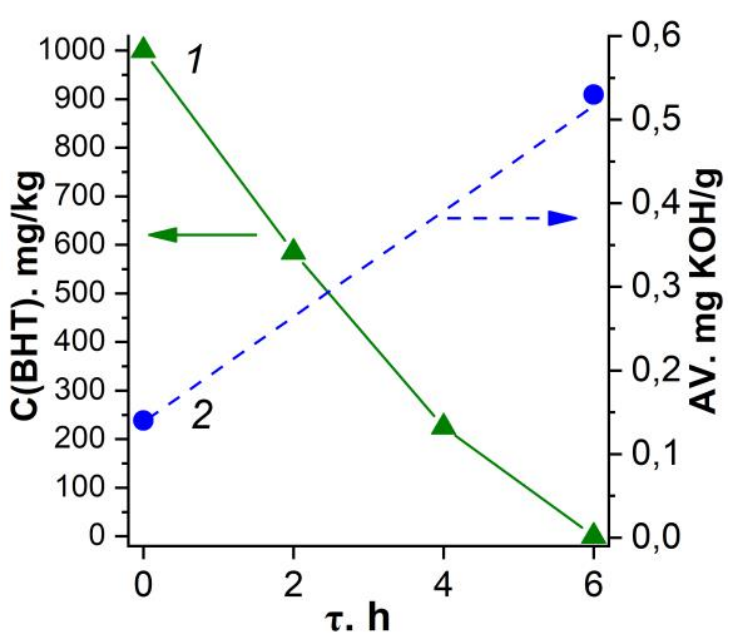

Fig. 6. Changing of BHT content (1) and acid value (2) for the BRSOD sample with initial BHT concentration $1000 \mathrm{mg} / \mathrm{kg}$ in course of oxidative treatment.

for fatty acids esters, namely for BWFOD sample, containing only about $6 \% \mathrm{C} 18: 2$ ester. The presence of tocopherols in BWFOD sample is questionable, since they may be consumed during utilization of initial oil in frying, as well as remained mainly in cube residue in course of butyl esters distillation. However, the presence of tocopherols cannot be surely excluded 
both for BRSOD and BWFOD samples. The results of work [32], in which ethyl esters of high-oleic sunflower oil $(78.8 \%$ C18:1, $12.5 \% \quad$ C18:2) were synthesized and characterized, looks interesting in this respect. Ethyl esters samples, purified via water washing, dry washing and distillation, were all characterized by unsatisfactory oxidation stability. But distilled sample has the lowest value of this parameter $\left(<1 \mathrm{~h}\right.$ at $\left.110^{\circ} \mathrm{C}\right)$, which is caused, from our point of view, by loss of natural antioxidants during distillation. But, as was mentioned above, initial high-oleic sunflower oil also contained synthetic antioxidant BHA (content is not specified), which also may contribute in the excellent stability of butyl esters. Its concentration in wasted oil, estimated from chromatogram, was only about $400 \mathrm{mg} / \mathrm{kg}$. Such a low content of BHT appeared to be totally ineffective to prevent degradation of the FABE sample with high C18:2 ester content. Moreover, BHA was fully consumed during the oxidation, which did not result in any changes of the composition of treated BWFOD sample. At the same time, BRSOD sample began to degrade before the full consumption of BHT. Thus, the presence of BHA probably enhanced the oxidative stability of corresponding FABE sample, in addition to its high stability due to fatty acid composition. Nonetheless, the results of current work prove the wasted frying high oleic sunflower oil as valuable and very suitable feedstock for biodiesel production. Its fatty acid composition, free from linoleic acid high content, provides not only high resistance for biodiesel oxidative degradation, but also prevents such a degradation in course of food frying. As result, wasted oil may contain lesser amount of polar admixtures, which is favorable for higher biodiesel yield, its easier purification and higher quality.

As for the chemical composition of the oxidation products and reaction pathways, leading to their formation, their elucidation was not the aim of current study. Much is said on this topic in literature, but sources mainly deal with FAME [12, 15, 33, 34]. Since the chemical alteration mainly affects the double bounds in the fatty acids moieties of esters, the nature of their alcohol moiety should not have the crucial effect on the oxidation stability. However, the decrease of induction period of oxidation in row methyl - ethyl - $n$-butyl esters were earlier reported [4]. Nonetheless of the chemical pathways of biodiesel degradation during oxidation treatment, BHT proved to be efficient in prevention of formation of both low-molecular oxidation products and products of oxidative polymerization. There exists question concerning the inconsistency of accelerated oxidation tests conditions to the conditions of long-term biodiesel storage. But earlier the authors of current work also proved the high efficiency of BHT antioxidant in preventing the degradation of butyl esters of linseed and rapeseed oils during their prolonged storing at ambient temperature under free access of the air and light exposure [35].

\section{Conclusions}

Results of current study have proven the high efficiency of alkaline-catalyzed route of fatty acid butyl esters synthesis using potassium butoxide catalytic solution. The latter may be produced using only potassium hydroxide and widespread monohydric alcohols. Transesterification of oils with $n$-butanol proceeds under mild reaction conditions (alcohol-to-oil molar ratio $-4.5-5.0$, temperature $-15{ }^{\circ} \mathrm{C}$, butoxide loading $\left.-1.4-1.6 \%_{\text {eq. KOH }}\right)$ within short reaction time (20-30 min) and results in 93-96\% molar yield of butyl esters. The reaction products are separated on its own mainly in course of synthesis, resulting in formation of primary glycerol layer, which contains predominantly glycerol and about three-quarters from loading alkali (more likely as potassium glyceroxide). Such primary glycerol layer may be useful for reuse in alkaline catalysis of oil transesterification or in other processes. Ester phases contains about $82-83 \%$ of butyl esters, only minor amounts of glycerol and soaps and no alkaline catalyst.

The sequence of purification operations, enabling to obtain biodiesel grade butyl esters was proposed. It includes removing of alcohol under vacuum, followed by additional phase separation, washing of obtained upper phase with water and vacuum distillation of washed butyl esters. In case of full conversion of fresh high-quality oil feedstock, it is also possible to obtain biodiesel-grade product without final distillation step.

The approach to the estimation of biodiesel oxidative stability, grounded on accelerated hightemperature oxidation with atmospheric air followed by gas chromatographic and titrimetric analyses, was developed. High oxidative stability of butyl esters, obtained from wasted frying high-oleic oil $(87.1 \%$ and $6.1 \%$ of oleic and linoleic acids), and unsatisfactory low oxidative stability of esters, originated from refined mid-linoleic sunflower oil $(25.3 \%$ and $61.2 \%$ of oleic and linoleic acids), were demonstrated. Addition of at least $2000 \mathrm{mg} / \mathrm{kg}$ of antioxidant 2,6-ditert-butyl-4-methylphenol was shown to be able to improve this characteristic to the level of biodiesel requirements.

\section{References}

1. The Biodiesel Handbook, $2^{\text {nd }}$ edn. (G. Knothe, J. Krahl, J. van Gerpen). Elsevier, Urbana, Illinois. 2010. 482.

2. Advances in Biodiesel Production. (R. Luque, J. Melero). Woodhead Publishing, Cambridge. 2012. 304.

3. Fonseca J.M., Teleken J.G., Almeida V.C., Silva C. Biodiesel from waste frying oils: Methods of 
production and purification. Energ. Conv. Manage. 2019. 184. 205-218.

4. Bouaid A., El Boulifi N., Hahati K., Martinez M., Aracil J. Biodiesel production from biobutanol. Improvement of cold flow. Chem. Eng. J. 2014. 238. 234-241.

5. Trypolska G.S, Podolets R.Z. The biofuels market in Ukraine. Economy and forecasting. 2017. N2. 75-92. [in Ukainian]

6. Konovalov S., Patrylak L., Zubenko S., Okhrimenko M., Yakovenko A., Levterov A., Avramenko A. Alkali synthesis of fatty acid butyl and ethyl esters and comparative bench motor testing of blended fuels on their basis. Chem. Chem. Technol. 2021. 15. 105-117.

7. Patrylak L.K., Zubenko S.O., Konovalov S.V., Povazhnyi V.A. Alkaline transesterification of sunflower oil triglycerides by butanol-1 over potassium hydroxide and alkoxides catalysts. Issues of chemistry and chemical technology, 2019. 5. 93-103.

8. Hájek M., Skopal F., Vávra A., Kocík J. Transesterification of rapeseed oil by butanol and separation of butyl ester. J. Clean. Prod. 2017. 155. 28-33.

9. Musil M., Skopal F., Hajek M., Varva A. Butanolysis: Comparison of potassium hydroxide and potassium tertpd-butoxide as catalyst for biodiesel preparing from rapeseed oil. J. Environ. Manage. 2017. 218. 28-33.

10. Homan T., Shahbaz K., Farid M. M. Improving the production of propyl and butyl ester-based biodiesel by purification using deep eutectic solvents. Sep. Purif. Technol. 2017. 174. 570-576.

11. Patent UA108271. Zubenko S.O., Okhrimenko M.V., Patrylak L.K., Voloshyna Yu.G., Yakovenko A.V., Konovalov S.V., Sushko N.M. The method of the catalyst preparing for biodiesel production. 2016. [In Ukrainian]

12. Yaakob Z., Narayanan B.N., Padikkaparambil S., Unni S.K., Akbar M.P. A review on the oxidation stability of biodiesel. Renew. Sust. Energ. Rev. 2014. 35. 136-153.

13. Yamane K., Kawasaki K., Sone K., Hara T., Prakoso T. Oxidation stability of biodiesel and its effect on diesel combustion and emission characteristics. J. Engine Res. 2007. 8. 307-19.

14. Dunn Robert O. Effect of temperature on the oil stability index (OSI) of biodiesel. Energy Fuels. 2008. 22. 657-62.

15. Kim. J.-K., Jeon Ch.-H., Lee H.W., Park Y.-K., Min K., Hwang I., Kim Y.M. Effect of Accelerated High Temperature on Oxidation and Polymerization of Biodiesel from Vegetable Oils. Energies. 2018. 11. 3514.

16. Nwafor O.M.I. The effect elevated fuel inlet temperature on performance of diesel engine running on neat vegetable oil at constant speed conditions. Renew. Energy. 2003. 28. 171-181.

17. Chuck C.J., Bannister C.D., Jenkins R.W., Lowe J.P., Davidson M.G., A comparison of analytical techniques and the products formed during the decomposition of biodiesel under accelerated conditions. Fuel. 2012. 96. 426-433.

18. McCormick R.L. Westbrook S.R. Storage stability of biodiesel and biodiesel blends. Energy Fuels. 2010. 24. 690-698.

19. Choe E., Min D.B. Mechanisms and factors for edible oil oxidation. Compr. Rev. Food Sci. Food Saf. 2006. 5. 169-186.

20. Russell G.A. Deterium-isotope effects in the autoxidation of aralkyl hydrocarbons. Mechanism of the interaction of Peroxy radicals. J. Am. Chem. Soc. 1957. 79. 3871-3877.

21. Wojdyło A, Oszmian'ski J, Czemerys R. Antioxidant activity and phenolic compounds in 32 selected herbs. Food Chem. 2007. 105. 940949.

22. Tang H, Wang A, Salley S, Ng KYS. The effect of natural and synthetic antioxidants on the oxidative stability of biodiesel. J. Am. Oil. Chem. Soc. 2008. 85. 373-82.

23. Patent UA123473. Zubenko S.O., Konovalov S.V., Patrylak L.K. The method of the catalyst preparing for fatty acid esters production. 2021. [In Ukrainian].

24. McCurry J.D., Wang Ch.-X. Analysis of Glycerin and Glycerides in Biodiesel (B100) Using ASTM D6584 and EN14105. Agilent Technologies. 2007.

25. Zubenko S.O. The simple method of vegetable oils and oleochemical products acid value determination. Catalysis and Petrochemistry. 2021. N31. 69-71.

26. Thoaia D.N., Tonguraia Ch., Prasertsita K., Kumar A. A novel two-step transesterification process catalyzed by homogeneous base catalyst in the first step and heterogeneous acid catalyst in the second step. Fuel Proc. Technol. 2017. 168. 97-104.

27. Pradhan S., Shen J., Emami S. et al. Synthesis of potassium glyceroxide catalyst for sustainable green fuel (biodiesel) production. J. Ind. Eng. Chem. 2017. 46. 266-272.

28. Ruiz-Méndez M.V., Marmesat S., Liotta A., Dobarganes M.C. Analysis of used frying fats for the production of biodiesel. GRASAS ACEITES. 2008. 59. 45-50.

29. Vieitez I., Callejas N., Irigaray B., Pinchak Y., Merlinski N., Jachmanian I. Grompone M. Acid Value, Polar Compounds and Polymers as Determinants of the Efficient Conversion of Waste Frying Oils to Biodiesel. J. Am. Oil Chem. Soc. 2014. 91. 655-664. 
30. Demurin Y., Scoric D., Karlovic D. Genetic variability of tocopherol composition in sunflower seeds as a basis of breading for improved oil quality. Plant Breed. 1996. 115. 33-36.

31. Aladedunye F., Przybylski R. Frying stability of high oleic sunflower oils as affected by composition of tocopherol isomers and linoleic acid content. Food Chem. 2013. 141. 2373-2378.

32. Pighinelli A.L.M.T., Ferrari A.R., Miguel A.M.R.O, Park K.J. High oleic sunflower biodiesel: quality control and different purification methods. Grasas Aceites. 2011. 62. 171-180.

33. Jakeria M.R., Fazal M.A., Haseeb A.S.M.A. Influence of different factors on the stability of biodiesel: A review. Renew. Sust. Energ. Rev. 2014. 30. 154-163.
34. Pullen J., Saeed K. An overview of biodiesel oxidation stability. Renew. Sust. Energ. Rev. 2012. 16. 5924-5950.

35. Zubenko S.O., Okhrimenko M.V., Kyrpach K.O., Konovalov S.V., Patrylak L.K. Degradation of ethyl and butyl fatty acids esters obtained from rapeseed and linseed oils during protracted storage and ways of its prevention. XXXI Scientific conference on bioorganic chemistry and petrochemistry of the Institute of bioorganic chemistry and petrochemistry of the NAS of Ukraine (Kyiv, March 31 - April 1, 2016) Catalysis and petrochemisty. 2016. N25. 95.

Надійшла до редакиії 24.11.2021 p. 


\title{
Бутилові естери соняшникової олії: синтез, очищення, окисна стабільність
}

\author{
С.В. Коновалов, С.О. Зубенко, Л.К. Патриляк, А.В. Яковенко \\ Інститут біоорганічної хімії та нафтохімії ім. В.П. Кухаря НАН України, Україна, \\ вул. Мурманська, 1, Київ 02660, Україна, konovalovserhiy@gmail.com
}

Дана робота присвячена одержанню, очищенню та покращенню окисної стабільності паливних бутилових естерів соняшникової олії як більш екологічної альтернативи метиловим естерам в ролі біодизелю. Олійна сировина включала зразки рафінованої соняшникової олії (кислотне число - 0,05 мг КОН/г; 25,3 \% i 61,2 \% олеїнової та лінолевої кислот) та використаної в смаженні високоолеїнової соняшникової олії (кислотне число - 1,20 мг КОН/г; 6,1% і 81,7 \% лінолевої та олеїнової кислот). Бутаноліз проводили за участі бутоксиду калію, одержаного 3 КОН та спиртів за оригінальним запатентованим способом, за м'яких умов (молярне співвідношення спирту до олії - 4,5-5,0, $15{ }^{\circ} \mathrm{C}, 1,4-1,6 \%$ екв. кон бутоксиду, 20-30 хв). Було одержано високий молярний вихід бутилових естерів (93-96 \%), а гліцерин та основна частина лужного каталізатора формували окрему фазу продуктів вже переважно в ході реакції. Естерову фазу піддавали очищенню 3 метою одержання бутанольного біодизелю паливної якості. Зразки після видалення бутанолу під вакуумом, наступного розшарування та відмивки і сушіння верхньої з одержаних фаз характеризувалися дещо заниженим вмістом естерів (94-95 \%), а вміст гліцеридів був вище дозволеного рівня. Вакуумна дистиляція як кінцевий етап очищення дозволила покращити склад продуктів до рівня вимого до біодизельного палива. Дистиляти містили близько 99 \% бутилових естерів, 0,4-0,5\% моногліцеридів, а н-бутанол, гліцерин, ди- та тригліцериди були фактично відсутні. Окисна обробка $\left(110^{\circ} \mathrm{C}\right.$, 6 год барботування повітря) продемонструвала високу окисну стабільність зразка, одержаного 3 використаної високоолеїнової олії, завдяки домінуванню в його жирнокислотному складі олеїнової кислоти. Зразок на основі рафінованої олії (переважно лінолева кислота в жирнокислонтому складі), продемонстрував дуже низьку стабільність. Було показано, що введення принаймні 2000 мг/кг антиоксиданта 2,6-ди-третбутил-4-метилфенолу сприяє покращенню даної характеристики до рівня вимог до біодизельного палива.

Ключові слова: бутилові естери жирних кислот, біодизель, калію бутоксид, окисна стабільність, антиоксидант 